\title{
The Non-Pauper Insane: Private, Voluntary and State Concerns
}

One would think that our legislators imagined insanity to spring only from the pride of wealth or the misery of poverty. They have never thought of making provision for the lunatic of the great class which lies between. ${ }^{1}$

This observation, which appeared in an Irish Times editorial in 1860, summed up widespread public concerns that Irish asylums were failing to cater for a specific group: those who could not afford private care but were not considered destitute. Accommodation of this kind had been available in England since the eighteenth century, where the private, public and voluntary sectors gradually coalesced to form a 'mixed economy of care'. ${ }^{2}$ The Irish Times editors' incredulous tone is unsurprising, given that the government had shown enormous energy when intervening in other areas of Irish lunacy provision. ${ }^{3}$ At national level, the issue gained increasing importance, attracting the attention of government officials as well as igniting interest among the medical community, philanthropists and the national press. The overwhelming question was how, where and to what extent to provide for the 'great class which lies between'.

This question had resonated during the 1850 s, most notably during a commission of inquiry held between 1857 and 1858. This commission was established to inquire into the state of lunacy laws, lunatic asylums and other institutions for the 'custody and treatment of the insane' in Ireland. While not intended exclusively as an inquiry into fee-paying asylum care, its proceedings sparked journalistic interest in that issue, receiving coverage in the leading national newspaper of the day, the Freeman's

(C) The Author(s) 2018

A. Mauger, The Cost of Insanity in Nineteenth-Century

Ireland, Mental Health in Historical Perspective, https://doi.org/10.1007/978-3-319-65244-3_2 
Journal. ${ }^{4}$ Meanwhile, official reports on Irish asylums repeatedly voiced government and medical concerns. From 1823 until the formation of the medical lunacy inspectorate in 1845 , the prison inspectors were required to visit and submit reports on all receptacles for the insane in Ireland. In their reports, the prison inspectors provided rather sketchy outlines of each 'place of profit', focusing most of their attention on the burgeoning district system. The first medical lunacy inspectors, Dr. Francis White (1846-1857) and Dr. John Nugent (1847-1890) drew clear distinctions between private and district asylums and delineated 'mixed' or voluntary asylums as a category in their own right. White, Nugent and their successors, Dr. George William Hatchell (18571889), Dr. George Plunkett O'Farrell (1890-1907) and Dr. E. Maziere Courtenay (1890-c. 1911) reported annually on Irish asylums. Their reports did not follow a specified format and the statistical data included varied from year to year. The inconsistent nature of these data poses difficulties when attempting to trace trends at specific intervals and, for this reason, statistical information examined in this chapter is often selective.

This chapter surveys national concerns about the admission of paying patients to private, voluntary and district asylums. It reviews proposals to establish separate accommodation for paying patients, negative coverage of private asylums by the press and lunacy inspectors, the growing social importance of Ireland's four voluntary asylums and the implications of the eventual reception of paying patients in district asylums. Ultimately, it argues, in the absence of a single effective solution to the problem of maintaining 'the great class which lies between', district, voluntary and private asylums came to provide distinct forms of care.

\section{'Confinement of the Higher Orders'}

In Ireland, private asylums played a relatively small role for much of the nineteenth century. In comparison with England and Wales, they were slow to develop. The origins of the earliest private asylums remain obscure, as were the grounds on which they were established. ${ }^{5}$ Prior to 1800, Cittadella in County Cork (est. 1799) was the only private asylum in Ireland. During the 1810s and 1820s, a number of small-scale establishments sprang up, mainly located in Dublin. The remainder of the century saw greater expansion, with the establishment of a further twenty-eight private asylums between 1840 to 1900. Unremarkable for a period of economic prosperity, thirteen of these asylums had appeared during the 1860s and 1870s. Yet, the depression which began in 1879 
and continued until the mid-1890s witnessed only a small decline in patient numbers, while the number of private asylums reached a peak of twenty in 1890. Nonetheless, some institutions, such as Rose Bush House in Dublin and the private asylum at Moate in Westmeath, remained open for less than a year. Others, such as Rathgar House and No. 174 Rathgar Road in Dublin, received only three patients each. As will be discussed, this period of depression also saw the closure of institutions which had been in operation for quite some time.

These modest beginnings were probably the reason that, excluding annual inspection, private asylums evaded government reform until 1842. ${ }^{6}$ Early nineteenth-century legislators instead fixed their gaze on the burgeoning district system. The Private Asylums (Ireland) Act of 1842 significantly extended central government's regulatory control over private asylums and sat well with contemporary political objectives towards centralisation, at a time when the state was rapidly reforming areas such as education, economic development, police, prisons and public health. ${ }^{7}$ As such, it may be viewed as just one element of the wider governmental reform sweeping through Ireland. Yet, the Act was the most important piece of legislation targeting non-pauper lunacy provision during the nineteenth century and in many respects brought Irish legislation in line with England and Wales, at least temporarily.

The 1842 Act aimed to increase protection for private patients. It introduced licensing measures, in place in England and Wales since 1774, and a rigorous tightening up of regulations. ${ }^{8}$ New measures included more frequent and unannounced inspections, while paying patients now required medical certification by two doctors. ${ }^{9}$ The latter signalled official recognition of public hysteria over the perceived vulnerability of private patients to wrongful or over-lengthy confinement; pauper patients required only one medical certificate. Finnane suggests this disparity resulted from the assumption that 'no advantage, other than a social one, would accrue to the partners in the committal of a poor person'. By contrast, legislators considered private patients to be at risk of wrongful confinement for the pecuniary advantage of their relatives. ${ }^{10} \mathrm{In}$ England and Wales, similar protective procedures for private patients had been in place since $1828 .^{11}$

Although these regulatory measures might have inspired the public's confidence, the reality was different. By 1860, the editors of the Irish Times had launched a tirade against private asylums, labelling them a 'crying evil', 'moral pest-houses' and appealing that these 'engines of ill so monstrous are swept from our land'. The editors went further, 
expressing disbelief that 'any person would be so hardhearted as, knowing the nature of these dens, to consign an afflicted relative or friend to such misery and woe'. ${ }^{12}$ The three key areas under criticism had been summarised in an article the previous year. Firstly, the editors were especially sceptical about the agendas of private asylum proprietors, pointing out that it was in their best financial interests to retain patients rather than cure them. Secondly, they heavily criticised the families of patients for failing to care for them in the home. In doing so, they revealed that their issue lay more with confinement itself, rather than any unpleasant conditions identified in the private asylums:

To read the prospectus of some Private Asylums, we would fancy them to be each a little paradise. Employment is provided, and amusement. There are games, balls, private theatricals, and concerts. In fact, all are to be treated as 'members of a family.' Why, then, does not the family to which a lunatic belongs provide all this solace which we are so ready to pay for? Why must we cloak our selfishness under the guise of affectionate relationship? Why must we bury each insane member of our kindred, as we do our dead, out of our sight, and comfort ourselves with the complacent notion that we pay largely to provide a haven for him?

Finally, the editors turned their attention to the cure rates which had been published in the inspectors' report for the year ending April 1859. Having provided some rather inconsistent calculations, the editors concluded 'it would appear, then, that the District Asylums offer, at least, as great a chance of cure as the most pretentious of Private Licensed Houses'. ${ }^{13}$ Comparing the figures provided by the inspectors confirms that the proportion of cures to admissions for district asylums was higher (49.3\% for year-end March 1859) than for those admitted to private asylums (40\% for year-end December 1859). As Chap. 3 will outline, while cure rates for patients admitted to St John of God's, Hampstead and Highfield tended to be higher than those to the voluntary and district asylums studied, the proportion of those discharged relieved was higher than for pauper patients admitted to the district system. ${ }^{14}$ As will be discussed, the high rate of those discharged prior to being 'cured' can be interpreted as evidence against the over-lengthy confinement of private asylums' patients for financial gain.

The editors' criticisms echoed those expressed in Britain since the eighteenth century, where humanitarian reformers challenged private 
asylum care as 'cruel in nature and inadequate in scale'. ${ }^{15}$ In fact, the Irish Times reprinted reports of the English Commissioners in Lunacy as evidence of the abuses in the private asylum system. ${ }^{16}$ In contrast, the Irish lunacy inspectors' commentary on private asylums was so positive in this era that Hampstead House published extracts of their 1861 report as a classified advertisement for that institution. ${ }^{17}$ In his comprehensive study of English and Welsh private asylums, William Ll. Parry-Jones attributes the longstanding public prejudices against private asylums to an over-hasty acceptance of sensationalist disclosures. ${ }^{18}$ Likewise, in spite of sporadic condemnations by the press, there is no evidence of abuses in Irish private asylums before the 1860s. ${ }^{19}$

By the late 1860s, the lunacy inspectors' views on private asylums had become more mixed. In 1867, they claimed that many private asylums, including Farnham House, Hampstead House and Lisle House in Dublin and the Midland Retreat in Queen's County (now County Laois) were 'admirably conducted and the patients in them treated with great care and attention, their personal wants, comforts and cleanliness being sedulously attended to'. However, the inspectors described other, unnamed, private asylums as 'less satisfactory' and reported they had administered 'very severe rebukes for culpable neglect in several instances'. In one case, having visited an unnamed Dublin private asylum in very cold weather and late in the evening, the inspectors found 'a want of fire and lights and an apparent disregard of order, cleanliness and comfort'. ${ }^{20}$ The inspectors did not identify these asylums in their reports, excerpts of which appeared in national and local newspapers throughout the nineteenth century. Had they exposed them, they might have dissuaded potential clientele from committing their relatives to these institutions. Although the 1842 Act had not vested the inspectors with the power to revoke licences, it stipulated they could recommend a withdrawal of a licence to the Lord Chancellor of Ireland, ${ }^{21}$ who, along with the Lord Lieutenant, ${ }^{22}$ had this authority. ${ }^{23}$ Yet Nugent and Hatchell did not exercise this authority. In their 1867 report, they wrote, 'were it not for the difficulty ... of providing other accommodation ... we would long since have recommended the withholding of licenses and closing the establishments'. ${ }^{24}$ The importance of this statement should not be overlooked. In the absence of any other provision, the inspectors claimed they had little alternative but to tolerate, if not partially obscure, the poor conditions prevailing in some of Ireland's private asylums. 
After 1867, little official attention was directed at private asylum conditions until the late 1880s, when the inspectors appeared to approve of the majority which were, they claimed, 'for the most part creditably conducted' and 'suitable abodes for patients in the better classes of society'. By this time, some private asylum proprietors were offering accommodation on a graded scale: while they still charged extremely high fees for most patients, they now provided inferior accommodation for others at much lower fees (see Chap. 3). As will be discussed, the inspectors took issue with these reduced rates of board but continued to display a fatalistic attitude towards conditions of care. ${ }^{25}$ Their approach to private asylums in this era reflects their declining authority and vitality towards the end of their careers. After 1870, the inspectors were apparently unable to go beyond the routine administrative function of their office and, by the 1880s, both inspectors were 'old, even invalid and had little energy to carry out their duties efficiently'. ${ }^{26}$ In this period, Nugent, who was reputed to have had a particularly difficult personality, came into conflict with asylum governors and central government, while the less controversial Hatchell was often too ill to carry out his duties. ${ }^{27}$ In his final report, Nugent had apparently resigned himself to the state of private asylums in Ireland, arguing it was his duty only to see that proprietors carried out the provisions of the legislation. ${ }^{28}$

In 1890, a new Lunacy Act was introduced in England, which prohibited the granting of any further private asylum licences and barred existing ones from expanding their accommodation. ${ }^{29}$ This development followed continuing pressure for reform, which included proposals to abolish the entire private system. As Parry-Jones reasons, this pressure was closely associated with concerns for the middle-class insane and criticism centred on the principle of profit underpinning the system. ${ }^{30}$ Meanwhile, in Ireland, the Lord Lieutenant appointed three commissioners to investigate current lunacy laws. These commissioners were Arthur Mitchell, a Scottish lunacy commissioner, R.W.A. Holmes, the Treasury Remembrancer for Ireland, and F.X.F. MacCabe, a medical inspector with the local government board. ${ }^{31}$ The commissioners drew attention to the English Lunacy Act but did not recommend corresponding restrictions for Ireland:

Private Asylums receiving patients in affluent circumstances will soon die, if they have not the confidence of the public and if they are not reported on favourably ... All classes of private patients are on the whole, in our 
opinion, best situated in asylums which are not carried on for the profit of proprietors. There are Private Asylums, however, in which the insane are treated with much skill and liberality and as Ireland does not possess great accommodation for private patients, either rich or not rich, in endowed and chartered institutions, we do not think it desirable to recommend prohibitive provisions like those of the new English Lunacy Law (1890) to be introduced into fresh Lunacy legislation for Ireland.

However, the commissioners condemned the maintenance of private patients at low rates, arguing it was 'difficult to obtain a profit ... without a stinting of necessary comforts and advantages'. ${ }^{32}$

The commission coincided with the appointment, in 1890, of two new lunacy inspectors, O'Farrell and Courtenay, who replaced Nugent and Hatchell. Although the new inspectors showed little imagination in administration or policy, they brought a new energy and were less complacent about poor asylum conditions. ${ }^{33}$ This latter appraisal also applies to the inspectors' attitude towards private asylums. From the outset, the new inspectors expressed discontent with private asylums, stating that with few exceptions they were 'not entirely satisfactory'. Like the 18901891 inquiry commissioners, the inspectors were strongly opposed to private asylums receiving patients at low rates, especially those containing only a few patients. ${ }^{34}$ In 1891 , they successfully recommended the withdrawal of a licence from Cittadella in Cork. The closure of Cittadella was a landmark event. The asylum was established and initially managed by the renowned mad-doctor and moral therapy enthusiast, Dr. William Saunders Hallaran, who published the first Irish textbook on psychiatry and had been influential in implementing moral therapy in district asylums. ${ }^{35}$ When its licence was revoked, Cittadella had been in operation for over ninety years. It is plausible the inspectors were making an example of Cittadella, sending a message to other private asylum proprietors that the inspectorate would not tolerate poor conditions of care.

Notably, the inspectors claimed to be protecting private patients whom they feared were not being given the 'comforts' and 'even luxuries' allegedly on offer in other countries. ${ }^{36} \mathrm{~A}$ few years later, they argued that private patients kept at low rates 'cannot afford those comforts which are now considered necessary for the treatment of the insane'. ${ }^{37}$ The inspectors feared proprietors lacked sufficient capital to operate in accordance with 'modern ideas' which could be seen abroad, though they did not specify what these ideas actually were. ${ }^{38}$ In spite of their 
remonstrance, the inspectors echoed the resolution of the 1890-1891 commissioners, concluding that 'high-class licensed houses will always be preferred by the wealthy and if not found to provide excellent treatment, they will very soon die out from want of patients'. ${ }^{39}$ Clearly, the inspectors now felt 'wealthy' families had the luxury of selection and in turn protection.

The closure of Cittadella signalled the inspectors' consolidation of their regulatory powers. Following this, they systematically identified poor conditions in private asylums, threatening to advocate the withdrawal of licences on several occasions. In addition to reporting on the general state of private asylums as a group, the inspectors began to append individual reports on each asylum. This represented a divergence from the old inspectors' practice of obscuring the identity of asylums they found fault with, and proprietors were visibly unnerved. For instance, in their 1895 report on Course Lodge in County Armagh, the inspectors stated:

We trust at the next renewal of the licence, the magistrates will consider the reports which my colleague and I have made during the past two years on this establishment and we would suggest if they see fit to renew the licence, that they obtain an undertaking in writing and forward a copy of same to our office, that the proprietor will in future receive only quiet and harmless cases. ${ }^{40}$

The following year, they reported that the Armagh Retreat had failed to record in the asylum books that a female patient had set fire to her clothes and sustained burns. They criticised this 'serious disregard of an important duty' and threatened that if they uncovered evidence of any similar neglect in the future they would recommend the asylum's licence be withdrawn. ${ }^{41}$ Even in cases where this was not threatened, the inspectors' simple expression of disapproval of a heating system or bed sheets met with rapid improvements. For example, in 1895, the inspectors were pleased to report that Belmont Park had taken steps 'to supply each bed with an under-blanket, as suggested in last report'. ${ }^{42}$

The influence of the new inspectors is further implied by the closure of several private asylums in the late nineteenth century. Of the ten that were established during the 1880s and 1890s, only two remained open in 1900, along with eleven pre-existing establishments. These were Belmont Park in Waterford and the House of St John of God (St John 
of God's) in Dublin. Their survival speaks volumes about the changing face of Irish private asylum care. Contrary to their criticism of other private asylums, the inspectors commended both Belmont and St John of God's for charging lower fees than other private asylums. Their praise was because both charged exclusively low fees, which they now felt safeguarded against inequalities between different classes of patients. ${ }^{43}$ This meant these asylums catered for a social group distinct from other private asylums and suggests that patients in these institutions did not have the same luxury of selection. In 1895, the inspectors acknowledged that in reality these hospitals met the needs of comparatively few patients (fewer than 100 between them in that year). ${ }^{44}$ However, in their last report, which included patient numbers for the year ending 1917, the lunacy inspectors recorded that Belmont and St John of God's had expanded to accommodate almost one-fifth of all private asylum patients. ${ }^{45}$ Despite the inspectors' unfaltering approval of these institutions, there were limitations. Each received only male patients and was run by a religious community: the Brothers of Charity managed Belmont and, as discussed earlier, the Hospitaller Order of St John of God managed and gave their name to that asylum. Both St John of God's and Belmont therefore maintained a strong Catholic ethos and catered primarily for men of that religion.

Reporting in 1898, the lunacy inspectors did not seem troubled by the closure of eight private asylums since their appointment. Instead, they appeared self-congratulatory in their claim that the asylums which had closed were the very ones receiving patients at low rates of board and 'must of necessity be open to suspicion'. ${ }^{46}$ Accordingly, in 1900, they reported:

a decided improvement has taken place in the accommodation provided in many of these houses and that there is a manifest desire on the part of most of the proprietors, to render the surrounding of their establishments in keeping with modern requirements for the care and treatment of private patients. ${ }^{47}$

Just ten years after their appointment, the inspectors alleged to have consolidated their influence over private asylums. They put forward, as evidence, a lack of abuses within the remaining thirteen private asylums. As the subsequent sections reveal, this development occurred in tandem with the expansion of alternative forms of non-pauper accommodation. 


\section{'The Great Class Which Lies Between'}

During the nineteenth century, there were several proposals for alternatives to private asylums. Official, lay and medical men frequently supported, debated and contested these various solutions. Beginning in the 1850s, official commentators, including the lunacy inspectors, advocated increased philanthropic activity, while the national press appealed for state-supported relief for the 'great class which lies between'. These public appeals may have been rooted in a realisation that public benevolence was failing to provide accommodation, but they were couched in criticism of private asylums.

The editors of the Irish Times demanded the replacement of private asylums with state-funded establishments catering for all social classes above paupers. ${ }^{48}$ Thomas Bakewell, the proprietor of Staffordshire private asylum (1808-1835) had imagined a similar system for England as early as 1814 . He recommended that the state should be the 'guardian of every lunatic' and oversee an alternative system of curative hospitals. Yet Bakewell's plans never came to fruition. Smith attributes this failure to the authorities' reluctance to raise the necessary funds, arguing that this vision was 'well beyond the level of intervention the politicians could contemplate'. ${ }^{49}$ While state intervention in Irish lunacy provision was well established by the $1850 \mathrm{~s},{ }^{50}$ dedicated facilities for paying patients seemed to lie outside the realm of government aid.

Contrary to the Irish Times' support for state involvement, some members of the Irish medical community strictly opposed it. For example, in the 1850s, Dr. James Foulis Duncan, who was visiting physician to several Dublin private asylums, including the expensive Farnham House, highlighted the potential shortcomings of a state-funded system, both in a dedicated treatise and in a letter to the Irish Times. ${ }^{51}$ Duncan, who clearly had a stake in private asylums, maintained that 'government asylums' would not prove an attractive alternative to the public. Presumably mindful of contemporary concerns about wrongful or overlengthy confinement in private asylums, he also claimed it was in their proprietors' financial interests to effect a 'large number of cures ... in a short time'. Duncan went on to warn that if government asylums were established, they would come to monopolise asylum care:

Admitting that the Government were even to do this, the question remains to be asked, will they create several asylums of each grade and by doing so, 
leave the parties requiring accommodation the power of selecting between rival institutions, so as to have in some measure the option of disposing their invalid relative where they may think most for his advantage? Or will they, by creating one only of each kind, virtually establish a monopoly which they must necessarily be satisfied with? ${ }^{52}$

Looking beyond his vested interest in private asylums, Duncan's views underscored some of the key criticisms of state intervention in nonpauper lunacy administration. Ironically, at the time Duncan was writing, private asylums had virtually established a monopoly on non-pauper lunacy provision in the absence of alternative care options.

By the 1860s, the lunacy inspectors were also agitating for the setting up of what they termed 'intermediate asylums' for non-paupers. Contrary to public demands, the inspectors recommended these asylums should be charitable, deeming provision for this social group 'a question of local importance' and therefore falling outside state responsibility. ${ }^{53}$ This mirrored the recommendations of the 1857-1858 commissioners, which concluded:

we should gladly see the existing [private] establishments of that class in Ireland give place to institutions of a self-supporting character and where this most helpless class would be cared for and maintained without reference to the profits to be derived from their infirmity. It is not to be expected that individuals will invest their capital, the source of support for themselves and their families, without looking for as large an income in return as it can fairly be made to produce, or that they will devote their time, labour and skills as professional men, to the care of the insane, from purely philanthropic motives.

In the face of this rather pessimistic assessment, the commissioners appealed to philanthropists:

Such an asylum ... would be an incalculable boon to society and we cannot but hope that in a city so remarkable for the charity of its inhabitants as Dublin the tide of benevolence may one day turn in this direction. ${ }^{54}$

Nineteenth-century Dublin certainly boasted an abundance of philanthropic initiatives in other areas of health and welfare provision. ${ }^{55}$ These initiatives took place against a backdrop of state provision that philanthropists often viewed as inadequate. ${ }^{56}$ Ratepayers resented their lack of 
authority over decisions about district asylums, particularly those incurring additional local taxation, ${ }^{57}$ and it is likely many would-be philanthropists were similarly loath to contribute towards voluntary asylums. By the late 1860s in Ireland, appeals for further voluntary provision for the non-pauper insane had ceased. As the subsequent section discusses, this resulted in part from the arrival of two new voluntary asylums in the previous decade.

\section{'A Highly Useful and Benevolent Foundation'}

In the 1850s, St Vincent's and Stewarts joined Ireland's two existing voluntary asylums, St Patrick's (est. 1757) and Bloomfield (est. 1812). Their arrival symbolised the recognition by two distinct philanthropic groups of the need for dedicated facilities for members of their own class or faith. These four establishments differed from private asylums in a number of ways. While the lunacy inspectors described certain private institutions such as St John of God's and Belmont as charitable, they singled out the four Dublin-based 'mixed' or voluntary asylums for sharing one attribute: they were not kept for profit. This had important implications for attitudes towards the voluntary sector. Amidst public anxieties over the potential wrongful or over-lengthy confinement of private patients by profiteering proprietors, the profits generated from voluntary asylum patients' fees were diverted to maintain charity patients or to make improvements to the accommodation and care provided. ${ }^{58}$ This practice, coupled with the lower fees they charged, resulted in voluntary asylums becoming the most widely used institutions for the non-pauper insane.

Each of the four voluntary asylums had strong religious affiliations, which in turn decided the sectors of society they served. St Patrick's, the first institution for the insane in Ireland, was founded in 1757 from the bequest of Irish writer and dean of St Patrick's Cathedral, Jonathan Swift. In her study of the hospital, Malcolm has shown that between 1841 and 1850, three-quarters of patients at St Patrick's were Church of Ireland, while between 1874 and 1883 they accounted for $81 \%{ }^{59}$ As already discussed, the second voluntary asylum, the Bloomfield Retreat, was set up by members of the Society of Friends in 1812 to provide relief for members of that persuasion. By its very design, Bloomfield was therefore intended principally for a minority group; by 1901, Quakers made up less than $2 \%$ of the population of both Dublin and Ireland. ${ }^{60}$ Until 
1821, only Quakers were admitted. However, the managing committee quickly realised that there was an insufficient number of Quaker patients to fill the available beds and began to advertise vacancies for non-Quakers. ${ }^{61}$ This followed suit with the York Retreat in England, which also began admitting non-Quaker patients at this point. ${ }^{62}$ The admission of patients from other denominations increased and, by 1858, only half of Bloomfield's patients were members of the Society-a discernible shift from the institution's initial sectarian ethos. ${ }^{63}$

Founded almost half a century after Bloomfield in 1857, St Vincent's asylum was superintended by an order of nuns called the Sisters of Charity and received only female patients. ${ }^{64}$ According to the lunacy inspectors, in 1857, Elizabeth Magan, sister of Francis, a barrister and high-ranking member of the United Irishmen, bequeathed 'many thousand pounds' to be used for 'some charitable purpose' in Dublin. Following Elizabeth's death, the relatives who inherited her property settled on establishing St Vincent's 'for the benefit of persons mentally affected belonging to the middle classes'. On opening, it could accommodate up to thirty patients and by 1870 it was reportedly 'full to capacity' at eighty-seven. The asylum subsequently expanded and by 1900 had more than tripled to accommodate 105 patients. Despite its Catholic ethos, and unlike the initial practice at Bloomfield, St Vincent's did not restrict entrance to members of one religious persuasion. ${ }^{65}$ Nonetheless, in 1896, approximately $70 \%$ of patients attended Catholic mass, which was said three times on Sundays and religious holidays, suggesting most patients were Catholic. ${ }^{66}$

Although, Stewart's motivations for founding his institution were primarily medical and philanthropic, the asylum also had a religious character. Stewart came from a strictly Church of Ireland background. His father, the Reverend Abraham Augustus Stewart, had been the rector of Donabate and chaplain to the Lord Lieutenant of Ireland and this influenced the religious character at Stewarts. ${ }^{67}$ The children's institution, while open to patients of all religions, was conducted on what the inspectors termed 'Protestant principles', and religious instruction formed the basis of patients' training. This practice did not extend to the lunatic asylum, however, which boasted two paid chaplaincies, one Protestant and one Roman Catholic. ${ }^{68}$ Yet, as Chap. 4 outlines, patients admitted to Bloomfield and Stewarts were primarily Church of Ireland or Quaker. 
The innately denominational ethos of voluntary asylums is unsurprising. As Maria Luddy has reasoned, 'philanthropic provision in nineteenth-century Ireland was denominational provision'. ${ }^{69}$ In fact, Irish charities, and particularly those of a Protestant leaning, were often the subject of public mistrust and allegations of proselytising behaviour. ${ }^{70}$ These anxieties were deeply rooted in Irish Catholic grievances surrounding the Famine period, when evangelical missionaries used hunger as an instrument to win converts to the Protestant faith by providing soup in designated kitchens. ${ }^{71}$ Mindful of these apprehensions, many charities limited their assistance to members of their own denomination. ${ }^{72}$ Another way of guarding against such charges was to provide religious ministrations to patients of all denominations. Yet this did little to sway cautious family members who were undoubtedly cognisant of the religious character of institutions. As will be seen, members of one creed were unlikely to select asylums that primarily received patients of another.

In addition to catering chiefly for members of one religion, voluntary asylum care was aimed at those who could not afford expensive private asylum accommodation, often following a descent down the social scale. Dr. Thomas Fitzpatrick, who would later become the first medical officer at St Vincent's, told the 1857-1858 commissioners that St Vincent's was intended for the 'middle classes'. Highlighting the delicacy of these individuals' status, he stated that those:

belonging to the educated portion of the middle classes and depending on the continued exercise of their talent and industry, fall at once, when affected with even temporary mental disorder, from comfort to ruin and whose families are hopelessly dragged down with them to poverty and want ... the class between the rich and the poor suffer without resources and often long unknown, till the prolonged pains and grief of concealed poverty beset and torture them; and no relief presents itself until they have wholly fallen into the ranks of paupers. ${ }^{73}$

Fitzpatrick's evidence reflected contemporary unease about the fragility of social status. Even beyond those seeking asylum care, individuals who encountered a sudden change of fortune met with sympathy both from Irish Poor Law guardians and charitable organisations. ${ }^{74}$ For example, the applications of middle-class women to charitable organisations tended to be subject to different criteria from those from the working 
classes, with social class often determining the type of aid given. ${ }^{75}$ These practices were the result of philanthropists' anxieties about the delicate nature of their own financial security and status in society. Writing about the Association for the Relief of Ladies in Distress through NonPayment of Rent in Ireland, Luddy has found that the comparable social backgrounds of the committee and the charity's recipients, combined with the realisation a similar fate could befall them, spurred the committee to action. She also asserts "the possibility that such "ladies" could be forced to enter a workhouse was greeted with horror'. ${ }^{76}$ Likewise, members of the public agitating for asylum provision for the middle classes were evidently concerned with the relief of their own social class. In 1874, a contributor using the pseudonym 'middle class' wrote to the Irish Times highlighting the want of increased asylum provision for the middle classes, which he argued would be a 'real boon to the community'. ${ }^{77}$

The managing bodies of voluntary asylums seemed anxious to cater for those who could not afford private asylum care. However, as Chap. 3 reveals, they often struggled to strike a balance between remaining charitable and financially solvent. As Ireland's system of district asylums expanded, St Patrick's patient base had become what Malcolm terms the 'middling classes' or those maintained at moderate sums. While this hospital's board of governors preferred even non-paying patients to be from the 'better classes' who had 'fallen on hard times', it was constantly compelled to adjust maintenance fees to simultaneously house the poor and attract wealthier patients. Tellingly, in 1845, most boarders were maintained at $£ 30$ or $£ 40$, yet by 1889 , free patients were no longer admitted and the minimum fee was raised to $£ 65$ per annum. ${ }^{78}$

At Bloomfield, the managing committee was chiefly concerned with providing inexpensive care to members of the Society of Friends. Contributions of $£ 100$ from a Society meeting or $£ 25$ from an individual Friend entitled the donor to nominate one 'poor patient' maintained at the lowest terms (minimum $£ 13$ p.a.). Private patients, meanwhile, were charged a minimum of $£ 26$ per annum or more, 'according to circumstances'. ${ }^{79}$ While Quaker patients were often received at these low rates and some free of charge, by the 1850s those of other religious persuasions were paying at least $£ 78$ per year. Bloomfield's superintendent, John Moss, attempted to account for this disparity, stating: 
those who are belonging to the Society of Friends have an especial claim to be admitted at the lowest rate ... because the Society in the first place subscribed the money for the purchasing of the ground and for the building and soforth [sic] and also additional sums in order that the additional expenses may in a great measure be defrayed. ${ }^{80}$

Although fees for Quakers competed well with private asylums, Bloomfield did not deliver affordable accommodation for those of other denominations. This was also the practice at the York Retreat, where by 1910, the lowest terms for Quaker patients were twelve shillings (approx. $£ 30$ p.a.), while non-Quaker patients were charged as much as seven guineas per week (approx. $£ 380$ p.a.). ${ }^{81}$

The two newer voluntary asylums offered more competitive rates. St Vincent's, which also admitted free and paying patients, charged on average $£ 21$ per year. ${ }^{82}$ The inspectors predicted early on that the institution would 'prove a very useful addition to the private lunatic establishments of this country' and praised the self-supporting nature of the establishment, from which the religious community would derive 'no emoluments whatever from their self-imposed duties'. ${ }^{83}$ Throughout the century, the inspectors continued to commend the institution's work. As has been discussed, Stewarts also offered 'moderate rates'. A letter to the editor of the Irish Times in 1874 stated that the hospital charged patients $£ 36$ per annum. ${ }^{84}$ Ireland's four voluntary asylums therefore offered varying rates at different points in their history. By the late nineteenth century, St Patrick's board of governors no longer admitted free patients, while Stewarts and St Vincent's apparently adhered more rigidly to their initial philosophy. Bloomfield, meanwhile, continued to charge nonQuakers fees on a par with private care.

A final defining feature of the four voluntary asylums was their exemption from the 1842 licensing legislation. Fitzpatrick explained the reasoning behind this practice in his evidence at the 1857-1858 commission, in his assertion that St Vincent's should be exempt because the expense of obtaining a licence:

takes away from the accumulation of funds intended for benevolent purposes. The object of such an institution is to increase or extend its benefits, in case there is any surplus arising from its receipts. ${ }^{85}$ 
In consequence, any revenue accumulated by voluntary asylums was exempt from tax.

Other sections of the 1842 Act did apply: the lunacy inspectors inspected all institutions, including voluntary asylums, and paying patients required certification by two medical men. ${ }^{86}$ Although voluntary asylums were subject to inspection, the exemption from licensing limited the lunacy inspectors' regulatory powers over them. In contrast to the anxieties of private asylum proprietors, outlined above, the managing bodies of voluntary asylums could choose to ignore the inspectors' advice. For instance, in 1897, the new inspectors complained about St Patrick's:

It does not appear that any of the suggestions made in our annual reports have received attention from the managing committee, but it is nevertheless our duty to go on from year to year calling attention to the very obvious requirements of the hospital. ${ }^{87}$

Failure to make these unspecified improvements may have resulted from a lack of financial resources. As Malcolm has argued, the government often demanded modernisation but offered no financial aid. ${ }^{88}$ But by the turn of the century, the inspectors praised St Patrick's, recording that 'a great deal of work' had been carried out. ${ }^{89}$ In the meantime, the inspectors continued to applaud other voluntary asylums, suggesting they tended to offer a high standard of accommodation.

Following the establishment of St Vincent's and Stewarts, and Bloomfield's expansion, increasing numbers of patients came to reside in voluntary asylums. Numbers in private asylums, meanwhile, declined, presumably because the more competitive voluntary asylums proved attractive to their potential clients (see Fig. 2.1). This indicates the existence of a market for voluntarism prior to the 1870s and reflects contemporary demand for accommodation for the 'middling classes'. From 1870 , there were consistently more patients in voluntary asylums than in private institutions.

Examined individually, a striking feature is the proportional decline in patients at St Patrick's (see Fig. 2.2). This can be attributed to mounting financial difficulties experienced by the institution. ${ }^{90}$ In consequence of the board's decision to raise patient fees, St Patrick's failed to compete with the other voluntary asylums. Despite the burgeoning popularity of 


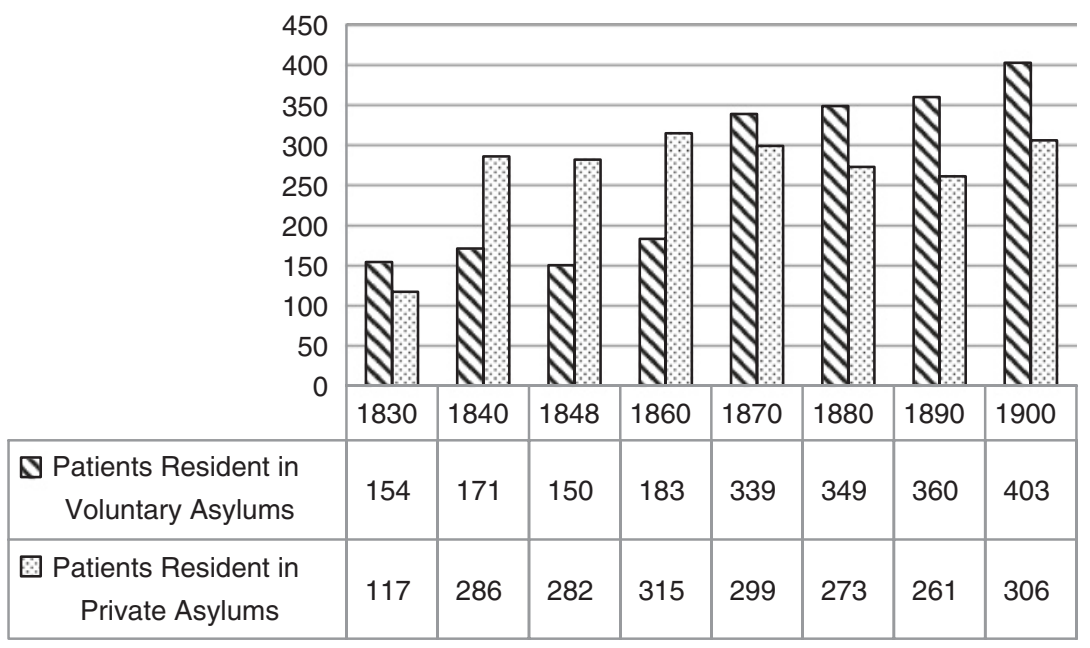

Fig. 2.1 Patient numbers in voluntary and private asylums in Ireland, 1830 to 1900. Compiled from Reports of the Inspectors General on the General State of the Prisons of Ireland, 1831, 1841; Reports on District, Local and Private Lunatic Asylums in Ireland, 1849, 1861, 1871, 1881, 1890-1891, 1901

voluntarism, no additional philanthropic initiative was launched following the establishment of Stewarts.

\section{'Asylums for the Lunatic Poor'?}

While it not is entirely surprising that the state was unwilling to finance separate accommodation for paying patients, it is striking that there was apparently no contemplation of a joint venture between state and charity. In England, following the introduction of the 1808 Lunacy Act, four such joint asylums were created, funded by both charitable bodies and the county and catering for pauper, charity and private patients. ${ }^{91}$ Instead, from the early nineteenth century, officials in Ireland paid increasing homage to the feasibility of housing paying patients in the public asylums, a practice introduced to England in 1815. There, fees for paying patients in the county asylums were competitive with the private sector, enabling wider access. ${ }^{92}$

In Ireland, families had been appealing for district asylums to admit paying patients since at least the 1830s. In 1835, the 'friends' of a female 


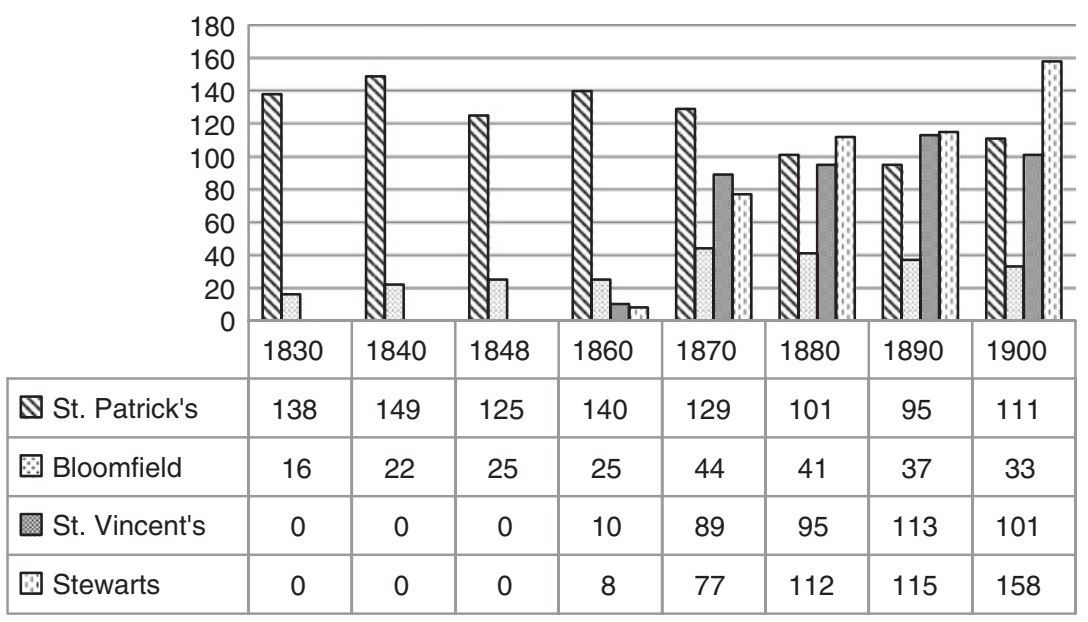

Fig. 2.2 Patient numbers in St Patrick's, Bloomfield, St Vincent's and Stewarts, 1830-1900. Compiled from Reports of the Inspectors General on the General State of the Prisons of Ireland, 1831, 1841; Reports on District, Local and Private Lunatic Asylums in Ireland, 1849, 1861, 1871, 1881, 1890-1891, 1901

lunatic applied to John Hitchcock, the manager of the Clonmel asylum, stating their willingness to pay for her care if he agreed to admit her. Hitchcock wrote to the Chief Secretary of Ireland for guidance. ${ }^{93}$ In his letter, Hitchcock recognised that district asylums were legally required to provide relief for the 'lunatic poor', whose qualifying affidavit for admission must state 'they are paupers and have no friend, who will, or can be obliged to support them in a private lunatic establishment'. On the other hand, Hitchcock was willing to acknowledge:

there are in this and other asylums a few, whose friends are many degrees above those belonging to the quite destitute poor - and though they might not be able to provide for them in a private asylum, yet might be brought, were it made a rule, to contribute at least, as much, as would indemnify the County for their maintenance.

Among this class, Hitchcock included people of reduced circumstances or limited incomes and large families, such as small farmers and secondrate shopkeepers. ${ }^{94}$ 
Clonmel was not the only asylum to receive applications of this sort. From the 1840s, the Richmond, Carlow and Maryborough district asylums had all begun to admit paying patients. Meanwhile, other asylums, including Belfast, refused to admit them until the practice was legally sanctioned. These earliest paying patients were maintained out of their own income or pension, the income from a farm or through contributions from their relatives. ${ }^{95}$ By 1857 , eleven district asylums housed fiftythree paying patients, who represented just over $1 \%$ of the total resident population. ${ }^{96}$ The lunacy inspectors' attitude towards the practice was inconsistent at this point. As Cox has argued, they simply attempted 'to excuse and justify it', while at the same time stressing their disapproval. ${ }^{97}$

The uncertainty shared by asylum board members and the inspectors can be attributed to several factors, including the Irish medical community's concerns that a payment system was open to both abuse and tax-payer resentment. ${ }^{98}$ In 1845, the newly appointed lunacy inspectors reported that the question of district asylums accepting paying patients warranted immediate and most serious attention on the part of the Government'. Apparently supporting this proposal, the inspectors maintained that local boards now favoured the measure and equivalent provisions were already in place in England and Scotland owing to the 'mixed character' of institutions there. ${ }^{99}$ While the inspectors were aware that mixing paying and pauper patients might create class distinctions between them to the disadvantage of pauper patients, they claimed it was the right of middle-and lower-class farmers 'to participate in the benefits of institutions, towards the erection and support of which they are assessed'. 100 This cohort comprised the local ratepayers for whom district asylums had become a heavy financial burden. ${ }^{101}$ Again, in 1852, the inspectors urged the propriety of admitting 'agriculturists and people in trade' who, under the present law, were 'in great measure debarred relief when labouring under insanity'. They advised against giving preferential treatment to paying patients and proposed that patients should be charged at the 'common annual expense for maintenance', stressing that this low rate should 'go simply to the support of the lunatic, without any derivable profit to a third party'. ${ }^{102}$

In 1856, attempts were made to legalise the admission of paying patients formally. The inspectors' influence was clear in a bill introduced 'to explain and amend the acts relating to lunatic asylums in Ireland'. ${ }^{103}$ This bill was primarily concerned with devolving future authority for appointments to the Irish executive. ${ }^{104}$ It also proposed a clause to 
legalise the admission of paying patients. ${ }^{105}$ However, when the bill was passed later that year, this clause had been omitted, most likely neglected due to controversies over asylum staff appointments. ${ }^{106}$ The following year, the question of legalising the admission of paying patients gained momentum during the 1857-1858 commission of inquiry, comprising Sir Thomas Nicholas Redington, Robert Andrews, Robert Wilfred Skeffington Lutwidge, James Wilkes and Dominic John Corrigan. The fact that these men were prominent members of their professions probably intensified the publicity surrounding the commission. Corrigan was a renowned member of the Irish medical community, the first Catholic president of the Royal College of Physicians of Ireland, had a private practice in Dublin and held numerous public appointments, often in relation to poor relief. Redington was an Irish administrator, a politician and a civil servant and held various posts including becoming the first Catholic Under-Secretary of State for Ireland (1846-1852) and Secretary to the Board of Control (1852-1856). ${ }^{107}$ Wilkes, previously medical superintendent at the Staffordshire county asylum in England (1841-1855) was also a commissioner of lunacy in England. Finally, Skeffington Lutwidge served as a legal member of the lunacy commission in England from 1855 until his death in 1873. Together, these commissioners interviewed the lunacy inspectors, resident physicians, visiting physicians, governors and chaplains at asylums throughout Ireland on various aspects of lunacy administration and legislation. The commission was a crucial forum and the extensive discussions of sanctioning the reception of paying patients in district asylums reveal the importance attached to this issue by mid-century. Their responses were as diverse as they were plentiful.

Several resident physicians, visiting physicians and board members were in favour of admitting paying patients, although they remained uncertain of the legalities. ${ }^{108}$ When queried, White claimed 'the law is so vague ... that in some asylums they refuse them'. He went on to recount the case of the Maryborough asylum board, which had applied to the inspectors for permission to admit a paying patient earlier that year. White had approved of the plan but then the board produced a document from 'some years past' which clearly showed that the law officers of the time had found 'that the law would not permit it'. 109 This was not the only discrepancy in the interpretation of the law regarding paying patients. For example, except for two pensioners, the Londonderry asylum did not cater for paying patients. Sir Robert Alexander Ferguson 
M.P., a member of the asylum boards at both Omagh and Londonderry, spoke about the irregularity within the system:

our idea in Derry has been that we had not a right to admit paying patients unless there was a superabundance of room; if there was room for more than the pauper patients that then we might admit the paying patients. That has been our understanding of the law both in Derry and in Omagh. At Omagh, having the room for them, we admitted them. ${ }^{110}$

In contrast, one governor of the Waterford asylum informed the commission 'I was always of the opinion it was not possible to do it under the existing law till Dr. White explained on the last Board day that it may be done'. ${ }^{111}$

Yet more confusion engulfed the question of whether families who could afford to pay only part of a patient's maintenance could do so. Board members and medical superintendents were particularly outspoken in this debate, touching as it did on their anxieties about the tax base for asylums. Although the Treasury initially covered construction costs for district asylums, ratepayers were required to repay these advances, meaning that the county rates ultimately funded the system. The counties were also expected to repay the total maintenance charges for patients, which the Treasury advanced. ${ }^{112}$ Thus, when it came to patients whose maintenance came only partially from private sources, the question of who would make up the difference was fraught with tension.

Several boards opposed the reception of these part-paying patients altogether, insisting that neither the state nor the local ratepayer should be obliged to subsidise them. Adopting a more moderate stance, Reverend Henry Montgomery, a member of the Belfast board, urged that only those able to pay $£ 5$ or $£ 10$ per year should be allowed to, asking 'what are you doing with public rates but supporting the poor?'113 Despite Montgomery's comments, at this point the Belfast board was still refusing to accept paying patients altogether.

Meanwhile, Samuel Haughton, a governor of the Carlow asylum, stated that his fellow board members were worried about the additional administrative pressure that admitting part-paying patients would create. Haughton feared it would be impossible to apportion payment according to patients' means, claiming that subsidising this group out of the local rates 'would be going from bad to worse, because they have not the machinery in the asylum to ascertain the truth with regard to the 
localities from which the persons came'. While Carlow had actually been admitting part-paying patients since at least $1854,{ }^{114}$ Haughton was correct in his forewarning. As Chap. 3 discusses, calculating means-appropriate fees became a time-consuming process for boards later in the nineteenth century. ${ }^{115}$

The medical community also held conflicting views about part-paying patients. The resident physician at Clonmel, Dr. James Flynn, argued that counties should not be compelled to support them. Mullingar's visiting physician, Dr. Joseph Ferguson, meanwhile, stated that lunatics were 'an interesting class', who, if 'allowed to go at large', produced multiple considerations for the state including crime, poverty and the extension of disease. In light of this, Ferguson maintained that the 'state ought to contribute any deficiency there might be, rather than throw it on the cess payers', contending it was up to the state to ensure the insane were institutionalised. ${ }^{116}$ This appeal was probably rooted in Ferguson's recognition of the state's role in providing for pauper lunatics. As Finnane has contended, insanity at this time was commonly viewed as providential and accordingly was characterised as a national rather than a local problem. ${ }^{117}$ Some asylum doctors in Ireland clearly subscribed to this view, which accounts for their demands for state recognition of the 'blameless' nature of the ailment. As will be discussed, the eventual outcome of these debates was to divide the outstanding maintenance for part-paying patients between the Treasury and the local rates, using the 'four shillings' rule.

Another concern about the reception of paying patients was whether they should receive superior food, clothing and accommodation. In theory, some argued, those who paid should be entitled to higher standards. However, proposals to provide better conditions for paying patients prompted anxieties both nationally and at local level. Many commentators feared that jealousies would arise between the pauper and paying patients. Nugent urged that both groups should be given identical accommodation and care, although he did not consider 'an injurious effect' would result from accommodating paying and non-paying patients together as 'the gradation is so imperceptible in social life'. 118 The Dean of Waterford asylum, Reverend Edward Newenham Hoare, adopted a contradictory stance, envisioning the number of 'difficulties' that might arise where paying patients' friends expected them to receive 'a mode of treatment as to dietary and other comforts better than what was ordinarily given to the pauper inmates'. ${ }^{119}$ 
Approaches to care for paying patients already in the asylums fluctuated widely. Most resident physicians favoured providing higher standards of accommodation. At Sligo, some paying patients were given 'every comfort they were accustomed to', along with a 'distinct attendant', and were housed in a separate ward. Fees were means-based and, in one or two cases, patients paid approximately $£ 1$ per week ( $£ 52$ p.a.) before being removed to a private asylum. Notably, the asylum's resident physician, Dr. John McMunn, was against continuing to care for these patients:

persons of that class require others of their own class to associate with them, in order to make them comfortable. It is most annoying to them to associate with persons of a lower class, which association, I think, materially retards their recovery. I think a pauper asylum totally unsuited to persons of a different class.

Sligo also received paying patients for as little as $£ 10$ per annum. Based on his experiences, McMunn prescribed a superior mode of care for paying patients, recommending that the 'rate-payers must pay the additional expense' incurred. He asserted that patients should be treated in a manner 'as near as possible to what they were accustomed to'. Thus, he stated, while pauper patients would receive their 'ordinary breakfast' of porridge, 'if a patient was accustomed to tea at home for breakfast, I would give him tea'. When one commissioner mockingly enquired whether McMunn might extend this 'to allow a man a carriage to drive in because he had been accustomed to one', McMunn disagreed. He did not share the concerns of several of his fellow resident physicians about the potential for jealousy between patients. ${ }^{120}$

Other asylum physicians and managers took pains to justify their preferential treatment of paying patients. Like McMunn, they framed their actions in terms of their moral obligation to accommodate patients in accordance with their previous living standards. For example, while the Ballinasloe asylum's manager, John B. M'Kiernan, placed non-violent paying patients in a 'better class' in the house, 'amongst the quiet and orderly', he attributed this to:

a moral point of view, as regards their moral treatment, thinking they have been accustomed to more comforts than they would have in this asylum 
as pauper patients and the want of which they would feel worse than the others. ${ }^{121}$

In relation to food, paying patients at Omagh were allowed 'nothing further than, perhaps, meat on Friday ... the day on which all the others get bread and milk'. They were also allowed to dress in their own clothes. ${ }^{122}$ Omagh's resident physician, Francis John West, assured the commissioners he had seen no instance of jealousy between patients and that there had been no inconvenience. At Killarney, paying patients invariably received a 'better class of food'. Martin Shine Lawler, resident physician and governor at the asylum, said he felt obliged to these patients, citing the following example:

there may be a paying patient who filled the rank of a gentleman; and who will not eat oatmeal gruel for breakfast and I am obliged to give him a more luxurious diet or better class of food.

Lawler conceded this had caused resentment, though he stated this was 'amongst persons who have been in a better position of life themselves, not amongst the humbler or poorer classes'. ${ }^{123}$

Only a minority of the resident physicians interviewed were against giving paying patients better treatment. Flynn warned of the confusion it would cause, resulting in 'interference with officers and servants corrupted and attempting to give patients advantages'. ${ }^{124}$ Limerick's resident physician, Dr. Robert Fitzgerald, maintained that he should not be expected to provide a higher scale of diet for paying patients. At Limerick, paying patients' friends were generally responsible for their clothing and frequently provided some food items. ${ }^{125}$ What emerged from the 1857-1858 inquiry was the uncertainty surrounding how best to accommodate this group, once admitted. It is plausible the asylum authorities felt a degree of sympathy for paying patients and were thus inclined to treat them preferentially. However, factors such as cost of accommodation and a sense of obligation towards the pauper patients also influenced these decisions.

On completing their inquiry, the commissioners found that the legislation did not 'appear to have contemplated the reception of paying patients', stating that the terms: 
which indicated that Asylums were to be erected for the 'lunatic poor,' are not to be and, indeed, have not been, considered as limiting them to the 'destitute poor,' or those whom, by that technical definition, the law recognises as qualified to be relieved out of the poor rates.

They recommended that the admission of paying patients should be 'distinctly recognised' to protect the ratepayers from 'undue taxation' and the lunatic poor from 'unfair encroachment upon the accommodation intended more especially for them'. The commissioners also advised that managers should make no distinction between paying and pauper patients, unless, with the knowledge of the physician, their friends supplied extras. Finally, they suggested that paying patients should be entitled to wear their own clothes in the asylum, though they encouraged the extension of this privilege to all patients. ${ }^{126}$

Despite its emphasis on paying patients and the resulting publicity, the commissioners' report did not generate any new legislation either sanctioning or regulating their admission. On 12 June 1860, an editorial in the Irish Times criticised the inquiry's outcome. This editorial cited Flynn's interpretation of the inquiry:

the volumes of evidence are taken; a report in the face of the weight of evidence is made. Then the Commissioners differ and publish separate reports; counter reports in vindication are got up and published; the public is divided; statesmen who know nothing of Ireland are puzzled; and, at last, all legislation is 'abandoned'.

Here, Flynn referred to the letters of dissent written by various individuals, including Corrigan and the Governor of Belfast, to the Chief Secretary. ${ }^{127}$ In 1859 , Nugent also wrote to the Chief Secretary reviewing the findings of the commissioners' report and reiterating his support for the admission of paying patients. ${ }^{128}$ The Irish Times editorial also related Flynn's recommendations for district asylums:

every county should have its own Asylum, with at least 200 beds, of which 30 should be allocated to paying patients, at $£ 20$ or $£ 30$ each per annum. These, with one chronic hospital for each province, would accommodate 8000 lunatics of the humbler and middle classes. ${ }^{129}$ 
This proposal garnered support from the press. The editors were advocates and the following day, a local paper, the Nenagh Guardian, characterised Flynn as the 'able physician' who offered 'some excellent suggestions'. 130

Despite the commission's failure to engender new legislation, public interest in the paying patient question persisted. In 1864, the Freeman's Journal reprinted an editorial from another local paper, the Clonmel Chronicle, in which the editors argued:

For rich and for poor - the millionaire, the tradesman, the mechanic and the pauper - for all classes and grades, there ought to be accommodation according to the means which can be afforded by the relatives of the patients, in public asylums.

They acknowledged that Flynn had been pressing this issue since the 1840s and complained that 'twenty years have since passed away and nothing has been done as yet'. ${ }^{131}$ It is plausible that the foundation of St Vincent's and Stewarts and expansion of Bloomfield in the intervening decades had somewhat pacified appeals for state provision, alleviating the pressure on the state to provide for this group.

\section{The Privy Council Clause}

Whether or not public pressure played a role, in 1870 a clause was added to the Privy Council's rules for asylums authorising the admission of paying and part-paying patients to district asylums. ${ }^{132}$ These rules contained limiting measures which largely echoed the commissioners' findings. As Cox has outlined, it prohibited access for paying patients in cases where pauper admissions were pending. Unlike entry as a pauper, paying patient applications required a certificate signed by a magistrate and a clergyman, verifying the applicant's unwillingness or inability to pay for private asylum care. While resident medical superintendents were tasked with submitting applications to the asylum board, the inspectors had the final say, as no paying patients could be admitted without their prior approval. Patient fees could not exceed the average cost of maintaining a pauper patient and could be no less than one-quarter of that amount. In real terms, this was between approximately $£ 6$ and $£ 24$ per annum, making it the least expensive asylum accommodation in Ireland, and protecting district asylums from allegations of profiting from paying patients. ${ }^{133}$ 
In response to some asylum doctors' preferential treatment of paying patients, they would now be subject to the same rules and regulations as pauper patients 'in regard to their treatment, care and maintenance'. ${ }^{134}$

Those rules were greeted with exceptional optimism. Once the Privy Council regulated the admission of paying patients, the inspectors seemed to become more comfortable with the practice. ${ }^{135}$ They predicted that the rules would be 'of the greatest benefit to a number of persons hitherto without the advantages of asylum treatment' and reported that they met with 'very general approbation' from the various asylum boards. ${ }^{136}$ The report of the 1878-1879 Trench commission inquiring into Poor Law unions and lunacy went so far as to project that 'twenty-five per cent of the beds in district asylums would be occupied by paying patients, if admissible'. ${ }^{137}$ Yet, uptake remained limited and, after 1870, both the actual and proportionate numbers of paying patients dropped off (see Table 2.1). These figures are low compared with voluntary and private asylums. As seen earlier, between 1860 and 1880 , the number of patients in voluntary asylums rose from 183 to 349 , while those in private asylums had dropped from 349 to 261 . While the increase in voluntary asylum patients resulted largely from the establishment of St Vincent's and Stewarts in the 1850s, it also reflects the relatively small uptake of district asylum provision for paying patients. Numbers admittedly fell far short of the $25 \%$ anticipated by the Trench commissioners. From 1877, the inspectors recorded the number of paying patients admitted as opposed to numbers resident. As Table 2.2 indicates, only a small proportion of admissions to district asylums were paying patients. From 1890 onwards, the newly elected lunacy inspectors ceased recording the number of paying patients in district asylums altogether.

Rather sheepishly, the lunacy inspectors repeatedly attempted to account for the persistently low numbers of paying patients admitted to district asylums. Among their explanations was the limiting nature of the Privy Council rules. As Cox has rightly contended, the inspectors failed to consider the difficulties paying patients might face in attempting to secure admission. Overcrowding, coupled with the fact that pauper admissions were given preference, meant admission was a slow process that proved unpopular with families. ${ }^{138}$ When the Trench commissioners questioned Nugent about the inconvenient mode of admitting paying patients, he volunteered no solutions and essentially evaded discussion 
Table 2.1 Number of paying patients resident in district asylums and the proportion of paying patients to total patients resident in district asylums, $1857-1889$

\begin{tabular}{lcc}
\hline Year & Number of paying patients resident & (\%) Paying patients to total resident \\
\hline 1857 & 53 & 1.1 \\
1860 & 84 & 2.0 \\
1865 & 71 & 1.5 \\
1870 & 122 & 1.8 \\
1875 & 91 & 1.2 \\
\hline
\end{tabular}

Compiled from Reports on District, Local and Private Lunatic Asylums in Ireland, 1857, 1861, 1866, 1871,1876

Table 2.2 Number of paying patients admitted to district asylums and the proportion of paying patient admissions to total admissions to district asylums, $1880-1890$

\begin{tabular}{lcc}
\hline Year & Number of paying patients admitted & (\%) Paying patients to total admitted \\
\hline 1880 & 65 & 2.8 \\
1885 & 57 & 2.0 \\
1889 & 53 & 1.8 \\
\hline
\end{tabular}

Compiled from Reports on District, Local and Private Lunatic Asylums in Ireland, 1881, 1886, 1890

of the problem by reciting the relevant sections of the Privy Council rules. ${ }^{139}$

In contrast to Nugent's apathy, various medical superintendents lambasted the 'difficulty and delay' the Privy Council rules occasioned. Dr. John Charles Robertson, medical superintendent at Monaghan, complained in 1878:

In the first instance the forms when perfected are submitted to the Board of Governors, who meet but once a month and the admission approved by them, then the form has to be forwarded to the Inspector's office for their approval and when returned to the Resident Medical Superintendent, approved, he can then notify the patient's friends, that the lunatic can be admitted.

Robertson recognised that these patients might be admitted provisionally, pending approval, but warned 'there is some trouble in making the 
friends fill up the forms agreeing to pay the sum stipulated'. Dr. William Daxon, medical superintendent at Ennis, also criticised this mode of admission, adding that on a medical superintendent's refusal to admit a paying patient, 'the friends commit the patients as a dangerous lunatic and the institution loses the benefit of the money'. ${ }^{140}$

Difficulties obtaining fees after patients had been admitted were reportedly widespread. ${ }^{141}$ Richmond's medical superintendent, Dr. Joseph Lalor, suggested that the Privy Council clause should be abolished, drawing the Trench commissioners' attention instead to the 1875 Lunatic Asylums (Ireland) Act. This Act allowed resident medical superintendents to apply to a court of summary jurisdiction to seize assets to the value of the fees owed, in cases where patients had means beyond those needed to support their family. ${ }^{142}$ If a patient had no assets, any person responsible for their support outside the asylum became liable for their maintenance once incarcerated. ${ }^{143}$ Lalor claimed these powers were sufficient to 'meet the cases of persons able to pay in whole or in part the cost of support' but were 'not carried out or very little carried out'. When he had, some years earlier, sent the Richmond board of governors a list of patients whose friends were believed to have means, the board 'had two or three cases put into the hands of their solicitor, but there was some difficulty in the way and it was not acted on'. ${ }^{144}$ According to Lalor, there had been between thirty and forty patients of this class at Richmond. ${ }^{145}$

Nonetheless, the proportion of district asylum patients 'supposed to have means' who did not contribute was reportedly low. According to the lunacy inspectors, they accounted for less than $1 \%$ of resident patients, both before and after the new Privy Council rules and the passing of the 1875 Act (see Table 2.3). In real terms, these patients numbered no more than forty in any one year.

Still at pains to explain the small number of paying patients, by the 1880 s the lunacy inspectors declared that the truth is there are no intermediate grades in Ireland sufficient for the purpose [of contributing towards their maintenance]'. At this point, the inspectors had almost completely reversed their former opinions on paying patients. They now suggested that the farming classes, the very people for whom they had previously urged the measure, should be immune to maintenance charges, because they had already contributed towards the rates. ${ }^{146}$ This factor likely deterred many families from applying to pay for care because they felt they had already contributed to the system. However, it is also 
Table 2.3 Proportion of paying patients and patients supposed to have means but do not pay to total resident population of district asylums in Ireland, $1865-1875$

(\%) Paying patients

\begin{tabular}{lcl}
\hline 1865 & 1.5 & 0.6 \\
1870 & 1.8 & 0.5 \\
1875 & 1.2 & 0.5 \\
1880 & Unknown $^{\mathrm{a}}$ & 0.3 \\
1885 & Unknown $^{1}$ & 0.3 \\
1890 & Unknown & 0.4 \\
\hline
\end{tabular}

aFrom 1880, the inspectors recorded the number of paying patients admitted to district asylums. Comparison between those resident from 1880-1890 is thus not possible. Compiled from Reports on District, Local and Private Lunatic Asylums in Ireland, 1866, 1871, 1876, 1881, 1886, 1890

conceivable that these claims were rooted in the decreasing prosperity of Ireland during this period as the economic depression worsened. In 1890, the new inspectors recognised that 'the poverty existing in Ireland will to a certain degree explain why the number supported, wholly or in part, by family contributions is so small'. ${ }^{147}$

The lunacy inspectors also blamed asylum boards. In 1874, a state grant of four shillings per head per week was introduced towards the maintenance of lunatics in public asylums in Britain and Ireland. ${ }^{148}$ This rule was important for paying patients. If the cost of maintenance in a district asylum was $£ 22$, patients paying approximately $£ 1112 s$ or less would be eligible for a Treasury grant. For patients charged more than this amount, the remainder came out of the local rates. The lunacy inspectors criticised the boards, whom they accused of 'best consulting the interests of the rate-payers by not putting pressure upon the relatives to contribute more than a certain amount' in order to qualify for the Treasury grant. ${ }^{149}$ However, this was apparently a temporary problem. By the late 1890s, the inspectors were 'glad to report' that the boards displayed 'greater energy' in obtaining fees. ${ }^{150}$

Paying for district asylum care also proved unpopular because standards of accommodation and treatment could not surpass those offered to pauper patients. ${ }^{151}$ Evidence given during the Trench commission suggests that families were reluctant to pay for the same level of care the pauper patients received free of charge. The disgrace of pauperising a 
family member was probably seen as payment enough. ${ }^{152}$ As Richmond's medical superintendent, Lalor, told the commission:

My experience is that people say, 'If I pay will my friends get better treatment?' and under the Privy Council rules they are not allowed to get better treatment and when they find this they let the thing go, as they say there is no advantage from paying.

Lalor also noted 'a great objection amongst people to let it be known that their friends are in an asylum', although he conceded that in some cases 'there is the proper pride not to have a person supported as a pauper who is not so'. ${ }^{153}$ Nugent portrayed Irish families in similar terms: 'they say that "if we go into a public asylum, why go in with the disgrace, while we are paying;" so they go in and don't pay.' When asked whether separate accommodation for non-paupers would 'meet a want largely felt', Nugent replied: 'I think it would in England, but it is not congenial to the feelings of the Irish', demonstrating the continued failure to gain official support for this proposal. ${ }^{154}$ As a means of compromise, Ennis' medical superintendent, Daxon, suggested that paying patients should be allowed to pay higher sums, 'as many of this class require better diet than the ordinary run of patients and their friends would much prefer to pay liberally for any extras that might be given to them'. ${ }^{155}$ By the late 1890 s, the lunacy inspectors concurred, arguing it was unfortunate that paying patients 'have to associate with persons below them in social position and education'. ${ }^{156}$ They proposed that the local authorities should be empowered to supply separate lodgings for paying patients. ${ }^{157}$ Still, by the turn of the century no drastic alterations took place and the Privy Council rules remained the principal guidelines for the reception of this group.

\section{Conclusions}

While Ireland was unusual for the early degree of state intervention in lunacy, provision for paying patients was slow to emerge. Because the private sector depended on profit, private care remained an expensive commodity out of reach for most of society, particularly during periods of economic hardship. Sporadic sensationalist press coverage of alleged abuses must also have deterred potential clientele. While by the end of the century, Belmont Park in Waterford and St John of God's in Dublin 
charged much lower than average fees, gaining favour with the lunacy inspectors, their scale and Catholic ethos left a large gap for others seeking affordable asylum care.

It was thus left to philanthropists and the state to grapple with how best to accommodate those between pauper and privileged. Contrasting discourses gave rise to two distinct solutions: the voluntary creation of mixed asylums catering for paying and charity patients, and sanctioning the admission of paying patients in district asylums. It was not until the founding of St Vincent's and Stewarts in the 1850s that voluntary provision became significant. These asylums offered moderate rates and even free accommodation to what they termed the 'middle classes' and the 'respectable poor'. Their managing bodies were sensitive to social distinctions between the various classes of patients and accommodation reflected the amounts charged. The state was more concerned with the protection of the poor, whom the district asylum system was initially created for, and the ratepayers who financed it. This resulted in the clumsily constructed Privy Council clause, which placed severe limitations on admissions and care for paying patients. Because of the varied agendas of these interest groups, non-pauper asylum care remained a patchwork of state, voluntary and private institutions, charging very different rates and offering vastly different standards of accommodation.

\section{Notes}

1. 'Editorial Article 2,' Irish Times, 12 June 1860.

2. Smith (1999a, p. 12).

3. MacDonagh $(1989$, p. 206).

4. 'Lunatic Asylums' Commission,' Freeman's Journal, 24 Oct. 1857.

5. For a discussion of the grounds on which Hampstead House, Highfield House and St John of God's were established, see Chap. 3.

6. 5 \& 6 Vic., c. 123.

7. MacDonagh $(1989$, p. 206).

8. 14 Geo. III, c. 49.

9. 5 \& 6 Vic., c. 123 , s. $14,15,18,20,28,30$.

10. Finnane (1981, p. 92).

11. Parry-Jones (1972, p. 17).

12. 'Editorial Article 1,' Irish Times, 29 Feb. 1860.

13. 'Editorial Article 1,' Irish Times, 12 Dec. 1859.

14. Ninth Report of the Inspectors General on the General State of the Prisons of Ireland, H.C. 1830-1831. 
15. Bartlett (1999, p. 48).

16. For example, 'Article 1,' Irish Times, 6 Oct. 1859.

17. 'Classified Ad 24,' Irish Times, 8 March 1861.

18. Parry-Jones (1972, p. 282).

19. Mauger (2012).

20. Report on District, Local and Private Lunatic Asylums in Ireland, H.C. 1867 , pp. 38-39.

21. The Lord Chancellor was the highest judicial officer in Ireland.

22. The Lord Lieutenant was the British monarch's official representative and head of the Irish executive.

23. 5 \& 6 Vic., c. 123 , s. 13 .

24. Report on District, Local and Private Lunatic Asylums in Ireland, H.C. 1867 , p. 39.

25. Thirty-Seventh Report on the District, Criminal, and Private Lunatic Asylums in Ireland [C 5459], H.C. 1888, lii, 595, p. 33.

26. Finnane (1981, p. 63$)$.

27. Cox $(2012$, p. 48).

28. Thirty-Eighth Report on the District, Criminal, and Private Lunatic Asylums in Ireland [C 5796], H.C. 1889, xxxvii, 641, p. 19.

29. 53 Vic., c. 5.

30. Parry-Jones (1972, p. 26).

31. Finnane (1981, p. 67).

32. Report of Committee on Lunacy Administration, p. 27.

33. Finnane (1981, p. 63), Cox (2012, p. 51).

34. Thirty-Ninth Report on the District, Criminal, and Private Lunatic Asylums in Ireland [C 6148], H.C. 1890, xxxv, 609, p. 4.

35. Cox (2012, p. 2), Kelly (2008, pp. 79-84), Kelly (2016, pp. 25-28).

36. Fortieth Report of the Inspectors of Lunatics (Ireland) [C 6503], H.C. 1890-1891, xxxvi, 521, p. 15.

37. Report into the State of Lunatic Asylums, Part II, p154. Forty-Third Report of the Inspectors of Lunatics (Ireland) [C 7466], H.C. 1894, xliii, 401, p. 23.

38. Forty-Second Report of the Inspectors of Lunatics (Ireland) [C 7125], H.C. 1893-1894, xlvi, 369, p. 15.

39. Forty-Sixth Report of the Inspectors of Lunatics (Ireland) [C 8639], H.C. 1897, xxxviii, 527, p. 39.

40. Forty-Fourth Report of the Inspectors of Lunatics (Ireland) [C 7804], H.C. 1895, liv, 435, p. 172.

41. Forty-Fifth Report of the Inspectors of Lunatics (Ireland) [C 8251], H.C. 1896, xxxix, Part II, 1, pp. 171-172.

42. Forty-Fourth Report of the Inspectors of Lunatics (Ireland), H.C. 1895, p. 181 . 
43. Fortieth Report of the Inspectors of Lunatics (Ireland), H.C. 18901891, p. 190; Report into the State of Lunatic Asylums, Part II, p. 154. Forty-Third Report of the Inspectors of Lunatics (Ireland), H.C. 1894, pp. 170-171.

44. Forty-Fourth Report of the Inspectors of Lunatics (Ireland), H.C. 1895, p. 22.

45. Sixty-Seventh Report of the Inspectors of Lunatics (Ireland) [CMD 32], H.C. 1919, xxv, 305, p. 39.

46. Forty-Seventh Report of the Inspectors of Lunatics (Ireland) [C 8969], H.C. 1898, xliii, 491, p. 30.

47. Forty-Ninth Report of the Inspectors of Lunatics (Ireland) [CD 312], H.C. 1900, xxxvii, 513, p. xl.

48. 'Article 1,' Irish Times, 14 Dec. 141859.

49. Smith (1994, pp. 191, 210, 212-213).

50. See Cox (2012), Finnane (1981).

51. Dr. James Foulis Duncan is not to be confused with his father, Dr. James Duncan, the proprietor of Farnham House Private Asylum. For more on James Foulis Duncan, see Kelly (2016, pp. 55-59).

52. Duncan (1853, pp. 257-258, 260-261).

53. Fourteenth Report on the District, Criminal, and Private Lunatic Asylums in Ireland [3556], H.C. 1865, xxi, 103, p. 13.

54. Report into the State of Lunatic Asylums, Part I, p. 32.

55. Preston (2004), Luddy (1995).

56. Luddy (2004).

57. Cox $(2012$, p. 19).

58. Twenty-Ninth Report on the District, Criminal, and Private Lunatic Asylums in Ireland [C 2621], H.C. 1880, xxix, 459, p. 22.

59. Malcolm $(1989$, p. 319). The remainder in both periods were Catholic.

60. 'Census of Ireland 1901.' Accessed 6 Jan. 2012, http://www.census. nationalarchives.ie.

61. Annual Report of the State of the Retreat, 1821, p. 5; Annual Report of the State of the Retreat, 1822, p. 4; Annual Report of the State of the Retreat, 1832, p. 5; Annual Report of the State of the Retreat, 1833, p. 5.

62. Digby 1985, pp. 180-181.

63. Report into the State of Lunatic Asylums, Part II, p. 162.

64. Eighth Report on the District, Criminal, and Private Lunatic Asylums in Ireland [2253], H.C. 1857, vvii, 67, p. 24; Fortieth Report of the Inspectors of Lunatics (Ireland), H.C. 1890-1891, p. 17; Fiftieth Report of the Inspectors of Lunatics (Ireland), H.C. 1901, p. 487.

65. Twenty-First Report on the District, Criminal, and Private Lunatic Asylums in Ireland, H.C. 1872, p. 33. 
66. The Forty-Fifth Report of the Inspectors of Lunatics (Ireland), H.C. 1896, p. 186.

67. O’Brien and Lunney (2002).

68. The Eighteenth Report on the District, Criminal, and Private Lunatic Asylums in Ireland, H.C. 1868-1869, p. 37.

69. Luddy (2004, p. x).

70. Preston 2004, pp. 52-55. For twentieth-century Ireland, see EarnerByrne (2007, pp. 75-82).

71. Whelan (1995, p. 135).

72. Preston (2004, pp. 52-55).

73. Report into the State of Lunatic Asylums, Part II, p. 195.

74. Crossman (2010, pp. 138, 141).

75. Walsh (2005, pp. 108-109), Luddy (1995, p. 176).

76. Luddy (1995, p. 191).

77. 'Middle Class Lunatic Asylums,' Irish Times, 23 Sep. 1874.

78. Malcolm (1989, pp. 118-120, 130-131, 176-178, 187).

79. Annual Report of the State of the Retreat (Dublin, 1811), p. 23.

80. Report into the State of Lunatic Asylums, Part II, p. 160.

81. Digby 1985, p. 181.

82. Eighth Report on the District, Criminal, and Private Lunatic Asylums in Ireland, H.C. 1857, p. 24.

83. Tenth Report on the District, Criminal, and Private Lunatic Asylums in Ireland [2901], H.C. 1861, xxvii, 245, p. 12.

84. 'Middle Class Lunatic Asylums,' Irish Times, 23 Sep. 1874.

85. Report into the State of Lunatic Asylums, Part II, p. 197.

86. 5 \& 6 Vic., c. 123 , s. 49.

87. Forty-Sixth Report of the Inspectors of Lunatics (Ireland), H.C. 1897, p. 209.

88. Malcolm (1989, pp. 175, 200).

89. Forty-Ninth Report of the Inspectors of Lunatics (Ireland), H.C. 1900, p. 217.

90. Malcolm (1989).

91. Smith (1999b, pp. 35, 37, 43).

92. Smith (1999b).

93. The Chief Secretary of Ireland was subordinate to the Lord Lieutenant. He was responsible for the British administration of Ireland and often sat in the British Cabinet.

94. John Hitchcock to the Chief Secretary of Ireland, 1835 (NAI, CSORP, $1835 / 3365)$.

95. Cox (2003, p. 78). See also Cox (2012, p. 21).

96. Eighth Report on the District, Criminal, and Private Lunatic Asylums in Ireland, H.C. 1857, p. 12. 
97. $\operatorname{Cox}(2003$, p. 78$)$.

98. Cox (2012, pp. 19-21).

99. For the English context, see Smith (1999b).

100. Report on District, Local and Private Lunatic Asylums in Ireland [820], H.C. 1847, xvii, 355, p. 12. See also Cox (2003, pp. 78-79).

101. See also Finnane (1981, p. 33), Cox (2012, pp. 18-20, 34-53).

102. Sixth General Report on the District, Criminal, and Private Lunatic Asylums in Ireland [1653], H.C. 1852-1853, xli, 353, p. 11.

103. A Bill to explain and amend the Acts relating to Lunatic Asylums in Ireland (149), H.C. 1856, v, 83, p. 3.

104. Finnane (1981, p. 38).

105. A Bill to explain and amend the Acts relating to Lunatic Asylums in Ireland, H.C. 1856, p. 3; Cox (2012, p. 22).

106. Cox (2012, p. 22), Finnane (1981, p. 38).

107. Redington was also actively involved in the Famine Relief Commission and received a knighthood for his services during the Famine.

108. Cox (2012, pp. 20-21).

109. Report into the State of Lunatic Asylums, Part II, p. 12.

110. Ibid., p. 215.

111. Ibid., p. 226.

112. Finnane (1981, p. 33). See also Cox (2012, pp. 18-20).

113. Report into the State of Lunatic Asylums, Part II, p. 346.

114. Cox (2003, p. 80).

115. See also Cox $(2012$, p. 23$)$.

116. Report into the State of Lunatic Asylums, Part II, pp. 318-319.

117. Finnane (1981, p. 57).

118. Report into the State of Lunatic Asylums, Part II, p. 36.

119. Ibid., p. 226.

120. Ibid., pp. 474,480 .

121. Ibid., p. 443.

122. Ibid., p. 397.

123. Ibid., pp. 486-487.

124. Ibid., p. 244.

125. Ibid., p. 382.

126. Report into the State of Lunatic Asylums, Part I, pp. 4-5.

127. Corrigan's key concern was that asylums should have visiting physicians. See Communication of Doctor Corrigan, dissenting from portion of Report of Commissioners of Lunatic Asylums, Ireland (95), H.C. 1859, xxii, p. 203; Correspondence relating to alleged Errors in Report of Commissioners of Inquiry into State of Lunatic Asylums of Ireland regarding Belfast Asylum (178), H.C. 1859, xxii, p. 237. 
128. Letter by Doctor Nugent, Inspector of Lunatic Asylums, in reply to Statements in Report of Commission on Lunatic Asylums in Ireland (147), H.C. 1859, xxii, p. 209.

129. 'Editorial Article 2,' Irish Times, 12 June 1860.

130. 'Lunacy and Lunatic Asylums,' Nenagh Guardian, 13 June 1860.

131. “"Middle-Class” Hospitals for the Insane,' Freeman's Journal, 20 Sept. 1864.

132. The Lord Lieutenant and the Privy Council were responsible for the formulation of asylum regulations.

133. Cox (2003, p. 81).

134. Twentieth Report on the District, Criminal, and Private Lunatic Asylums in Ireland [C 440], H.C. 1871, xxvi, 427, p. 163; Cox (2012, p. 22).

135. Cox (2003, p. 81), Cox (2012, pp. 22-23).

136. Eighteenth Report on the District, Criminal, and Private Lunatic Asylums in Ireland, H.C. 1868-1869, p. 38; Twentieth Report on the District, Criminal, and Private Lunatic Asylums in Ireland, H.C. 1871, p. 6.

137. Thirty-Second Report on the District, Criminal, and Private Lunatic Asylums in Ireland [C 3675], H.C. 1883, xxx, 433, p. 8.

138. Cox (2012, p. 23).

139. Trench Commission Report, p. 86.

140. Ibid., pp. 56, 230-231.

141. See, for example Ibid., pp. 56, 67, 87.

142. A Court of Summary Jurisdiction usually comprised two or more justices of the peace sitting in petty sessions. These assets included money, goods, possessions, rents and profits of the lands and tenements, and any other part of the patient's income.

143. 38 \& 39 Vic., c. 67 , s. 16.

144. Trench Commission Report, pp. 62, 67, 233.

145. Ibid.

146. Thirty-Second Report on the District, Criminal, and Private Lunatic Asylums in Ireland, H.C. 1883, pp. 8-9. Cox (2012, p. 22).

147. Fortieth Report of the Inspectors of Lunatics (Ireland), H.C. 18901891, p. 6.

148. For more on the impact of this rule on asylums and ratepayers see Finnane (1981, pp. 57-58). See also Melling and Forsythe (2006, p. 22).

149. Forty-Second Report of the Inspectors of Lunatics (Ireland), H.C. 1893-1894, p. 5.

150. Forty-Sixth Report of the Inspectors of Lunatics (Ireland), H.C. 1897, p. 9.

151. Cox (2003, p. 81). 
152. In his study of Australian asylums, Stephen Garton has cited the stigma associated with institutional confinement as a cause of the relatively poor rates of maintenance fee recovery. Garton (1988, p. 115).

153. Trench Commission Report, pp. 86-87.

154. Ibid., p. 86.

155. Ibid., p. 231.

156. Forty-Sixth Report of the Inspectors of Lunatics (Ireland), H.C. 1897, p. 39.

157. Forty-Fifth Report of the Inspectors of Lunatics (Ireland), H.C. 1896, p. 29.

\section{REFERENCES}

Bartlett, Peter. 'The Asylum and the Poor Law: The Productive Alliance.' In Insanity, Institutions and Society, 1800-1914, edited by Joseph Melling and Bill Forsythe, 48-67. London and New York: Routledge, 1999.

Cox, Catherine. 'Managing Insanity in Nineteenth-Century Ireland.' PhD diss., University College Dublin, 2003.

Cox, Catherine. Negotiating Insanity in the Southeast of Ireland 1830-1900. Manchester: Manchester University Press, 2012.

Crossman, Virginia. 'Middle-Class Attitudes to Poverty and Welfare in PostFamine Ireland.' In Politics, Society and the Middle Class in Modern Ireland edited by Fintan Lane, 130-147. Basingstoke: Palgrave Macmillan, 2010.

Duncan, James Foulis. Popular Errors on the Subject of Insanity Examined and Exposed. Dublin: Fannin \& Co., 1853.

Earner-Byrne. Lindsey. Mother and Child: Maternity and Child Welfare in Dublin, 1922-1960. Manchester: Manchester University Press, 2007.

Finnane, Mark. Insanity and the Insane in Post-Famine Ireland. London: Croom Helm, 1981.

Garton, Stephen. Medicine and Madness: A Social History of Insanity in New South Wales, 1880-1940. Kensington, New South Wales, Australia: New South Wales University Press, 1988.

Kelly, Brendan D. 'Dr. William Saunders Hallaran and Psychiatric Practice in Nineteenth-Century Ireland.' Irish Journal of Medical Science, 117, no. 1 (2008): 79-84.

Kelly, Brendan. Hearing Voices: The History of Psychiatry in Ireland. Newbridge: Irish Academic Press, 2016.

Luddy, Maria. Women and Philanthropy in Nineteenth-Century Ireland. Cambridge: Cambridge University Press, 1995.

Luddy, Maria. Foreword to Charitable Words: Women, Philanthropy and the Language of Charity in Nineteenth-Century Dublin. Westport, Conn.: Praeger, 2004. 
MacDonagh, Oliver. 'Ideas and Institutions, 1830-1845.' In A New History of Ireland V: Ireland under the Union, I, 1801-1870, edited by W. E. Vaughan, 193-217. Oxford: Oxford University Press, 1989.

Malcolm, Elizabeth. Swift's Hospital: A History of St Patrick's Hospital, Dublin, 1746-1989. Dublin: Gill and Macmillan, 1989.

Mauger, Alice. "“Confinement of the Higher Orders": The Social Role of Private Lunatic Asylums in Ireland, c. 1820-1860.' Journal of the History of Medicine and Allied Sciences 67, no. 2 (2012): 281-317.

Melling, Joseph and Bill Forsythe. The Politics of Madness: The State, Insanity and Society in England, 1845-1814. London and New York: Routledge, 2006.

O'Brien, Andrew and Linde Lunney. 'Henry Hutchinson Stewart.' In Dictionary of Irish Biography, edited by James McGuire and James Quinn. Cambridge: Cambridge University Press, 2002.

Parry-Jones, William Ll. The Trade in Lunacy: A Study of Private Madhouses in England in the Eighteenth and Nineteenth Centuries. London: Routledge \& Kegan Paul, 1972.

Preston, Margaret H. Charitable Words: Women, Philanthropy and the Language of Charity in Nineteenth-Century Dublin. Westport, Conn.: Praeger, 2004.

Smith, Leonard D. 'Close Confinement in a Mighty Prison: Thomas Bakewell and his Campaign against Public Asylums, 1810-1830.' History of Psychiatry, 5, no. 18 (1994): 191-214.

Smith, Leonard D. Cure, Comfort and Safe Custody: Public Lunatic Asylums in Early Nineteenth-Century England. London and New York: Leicester University Press, 1999a.

Smith, Leonard D. 'The County Asylum in the Mixed Economy of Care, 18081845.' In Insanity, Institutions and Society, 1800-1914, edited by Joseph Melling and Bill Forsythe, 33-47. London and New York: Routledge, 1999b.

Walsh, Oonagh. Anglican Women in Dublin: Philanthropy, Politics and Education in the Early Twentieth Century. Dublin: University College Dublin Press, 2005.

Whelan, Irene. 'The Stigma of Souperism.' In The Great Irish Famine, edited by Cathal Póirtéir, 135-154. Dublin: Mercier Press, 1995. 
Open Access This chapter is licensed under the terms of the Creative Commons Attribution 4.0 International License (http://creativecommons.org/licenses/ by $/ 4.0 /$ ), which permits use, sharing, adaptation, distribution and reproduction in any medium or format, as long as you give appropriate credit to the original author(s) and the source, provide a link to the Creative Commons license and indicate if changes were made.

The images or other third party material in this chapter are included in the chapter's Creative Commons license, unless indicated otherwise in a credit line to the material. If material is not included in the chapter's Creative Commons license and your intended use is not permitted by statutory regulation or exceeds the permitted use, you will need to obtain permission directly from the copyright holder.

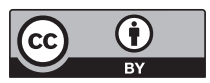

